\title{
The Black Holes
}

\author{
Borja GonzÁlez
}

Reservoir Books, 2018

A

rranquémonos con una pregunta casi metafísica: ¿poseen los tebeos banda sonora? La expresión es una apropiación evidente, no digamos ya el concepto, y la respuesta — si la hay- variará en función del sentido que le demos al mismo. Hay cómics acompañados eficazmente por un disco grabado ex profeso, existen también obras de cariz más personal a las que el autor de turno se ha preocupado de dotarlas de múltiples significados utilizando la letra de algunas canciones en el interior de los bocadillos, recomendándonos además en los apéndices con que sintonías acompañar la lectura, e incluso hemos leído reflexiones con forma de viñetas en torno al arte del pentagrama y a sus intérpretes. El requisito imprescindible es, en fin, saber graduar el volumen de la audición para subrayar la melodía o por el contrario usarla como contexto, desmigando algunas pistas pero

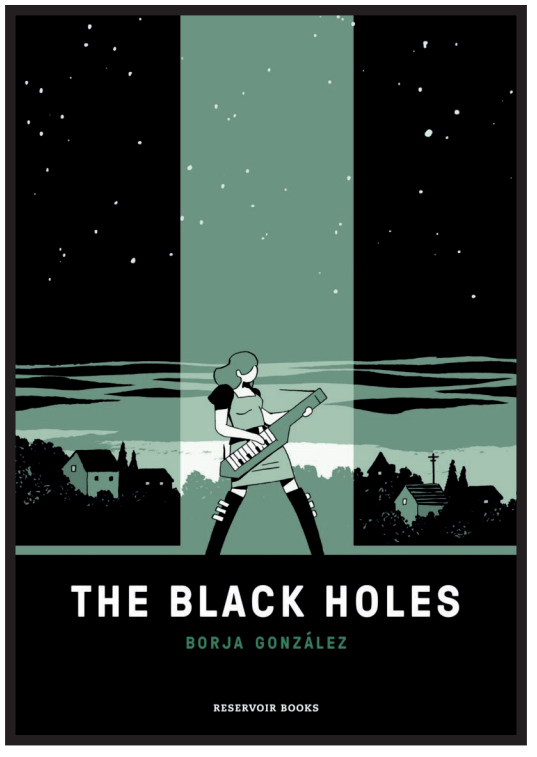
dejándolo más bien al albur del lector de turno.

En una conversación con Diego García Rouco para la página web Zona Negativa, el historietista extremeño Borja González reconocía algo parecido respecto a la importancia de la música en su último trabajo, The Black Holes, y no solo en lo referente a los grupos que escuchaba mientras lo dibujaba, sino a que un tema determinado, de clamorosas reminiscencias comiqueras (Ghost Rider de Suicide), que aparece referenciado además en sus páginas, «tiene una importancia capital a la hora de entender el tono de la historia». Podríamos quedarnos en la superficie entendiendo que el vínculo se circunscribiría a la mera intención de los personajes de esta novela gráfica de montar un grupo de punk rock, haciendo gala de sus cuestionables conocimientos para hacer sonar cualquier instrumento. Pero nos equivocaríamos de medio a medio, pues esa relación con la música es mucho más íntima, o más fuerte si se quiere, sin pretender - ¡atención! - ser unívoca. Aquí no se busca una contestación correcta, el acompañamiento no debe limitarse solo al corte que abría el primer LP de Marvin Rev y Alan Vega allá por 1977. Al contrario, lo que se percibe musicalmente es una indefinición intencionada que evocará en cada receptor canciones diferentes, dependiendo sobre todo de la respectiva educación sentimental y que puede sacar a la palestra géneros musicales situados a millas de distancia del No Wave. 
Si nos limitamos por ejemplo a lo que se vislumbra en la superficie de The Black Holes, es decir, a los escenarios, la ambientación y el diseño, podríamos traer a colación a un joven cuarteto que sigue evolucionando desde el pop clásico a la electrónica, el conjunto catalán Manel. En concreto dos de sus temas: La mort d'un heroi romàntic, claro, en el que el crítico Marcos Ordóñez vio la sombra de Josep Pla o de Rafael Azcona, y Les cosines, incluidos respectivamente en su tercer (Atletes baixin de l'escenari) y cuarto álbum (Jo competeixo). E1 primero por narrar un suceso enclavado cronológicamente en los mismos periodos que el título de González - el auge del romanticismo de mediados del xix y la actualidad-, por sugerir asimismo la analogía poética y sentimental entre ambos o por la mezcla audaz de anacronismos, y el segundo por compartir personajes femeninos tan carismáticos, capaces de escaparse a medianoche del baile en el que se las homenajea para ir a bañarse al río mientras la luna se mueve como un animal «platejant el sotabosc». Mostrándose así capaces, las canciones y el cómic, de transmitir la nostalgia, el misterio y la melancolía características de aquel ideal literario, de aquella fructífera corriente artística personificada en creadores como Shelley, Byron o Friedrich.

Gloria, Laura y Cristina, las protagonistas en grados diferentes de The Black Holes, siguen fieles al mundo creado por González en su tebeo anterior, La Reina Orquídea (El verano del cohete, 2015), con el que comparte el gusto por la teatralidad, la arquitectura decimonónica, el paisaje falsamente bucólico, el peso de las sombras y el desafío de lo desconocido, que recuerda por momentos a Mignola. La diferencia, sin embargo, entre aquel y este la marca, aparte de la extensión, la bidimensionalidad temporal del último libro. Efectivamente, como si decidiera experimentar en la práctica una supuesta hipótesis científica acerca del funcionamiento interno de los agujeros negros, capaces entonces de conectar dos épocas distanciadas por un siglo y medio, González rastrea un hilo invisible que ata a dos mujeres creativas e inconformistas, incomprendidas e inclasificables, ahogadas por sus entornos y por quienes las rodean. Y lo hace lejos del melodrama, tan lejos que por momentos es comedia adolescente, cuando no macabra ópera rock o adaptación ilustrada de Emilie Brönte. Resuelto siempre de un modo conciso, sin perderse en el bosque que él ha hecho crecer, y confiando además, y completamente, en los recursos que el lenguaje del cómic le brinda (la ausencia de rostros, y por lo tanto de gestos, de matices expresivos, el tratamiento del color, las líneas cinéticas).

Construido en base a viñetas de gran tamaño y parrillas variables según convenga, de narratoria clásica, diálogo nítido y grafismo sencillo, el tebeo de Borja González es rico en referencias, homenajes, metáforas, máscaras (y disfraces) y juegos de espejos, que no devuelven precisamente un reflejo exacto, ni siquiera su contrario. Sus heroínas pretérita y contemporánea se han descubierto mutuamente, más por las propias carencias sentimentales que sufren que por los vínculos íntimos que las puedan unir. A través de las experiencias de cada una de ellas se ponen en solfa las férreas normas sobre las que se sustentan la familia y la amistad, en suma las dos grandes instituciones sociales. El peso de la tradición, el modo como el colectivo anula al individuo o la necesidad de aparentar quien no se es para ser aceptado son asuntos que se abordan indirectamente al tiempo que se plantean otros interrogantes. Disimulado como representación afectada, el discurso se cuestiona el hecho 
mismo de crear, interrogándose acerca de la procedencia de las musas y el origen de la inspiración.

Un ejercicio ambicioso que defiende por encima de todo que el arte, las canciones y los poemas no tienen porqué tener lógica. Y que se puede empezar cantando sobre un cadáver y acabar con dos párrafos de jerga científica - Manel sigue estando aquí muy cerca-, igual que se es libre de dedicar unos versos a un velocípedo de fuego sin que se sepa muy qué demonios es.

Óscar Gual Boronat 